\title{
Effect of Self Efficacy and Prior Knowledge on Students' Skills
}

\author{
Ryan Permana, S.T., M.Pd ${ }^{1)}$, Febrianto Sabirin, S.Kom., M.Pd ${ }^{2)}$, Vindo Feladi, S.T.,M.Pd ${ }^{3)}$ \\ ${ }^{1)}$ IKIP-PGRI, Pontianak, Indonesia \\ Email: ryanpermana.hidayat@gmail.com \\ ${ }^{2)}$ IKIP-PGRI, Jalan Ampera No. 88, Pontianak, Indonesia \\ Email:rinakasaka@gmail.com \\ ${ }^{3)}$ IKIP-PGRI, Jalan Ampera No. 88, Pontianak, Indonesia \\ Email:vindo.feladi@gmail.com
}

\begin{abstract}
This research aims to determine: (1) Information about the information of self-efficacy, prior knowledge, and skills of students in the subject of Advanced Computer Network course in Information and computer technology education IKIP PGRI Pontianak, (2) The effect of self efficacy on the skills of students in the subject of Advanced Computer Network course in Information and computer technology education IKIP PGRI Pontianak, (3) Effect prior knowledge of the skills of students in the subject of Advanced Computer Network course in Information and computer technology education IKIP PGRI Pontianak, and (4) The effect of self-efficacy and prior knowledge of the skills of students in the subject of Advanced Computer Network course in Information and computer technology education IKIP PGRI Pontianak. This research is an ex-post facto research with correlation design. The independent variable in this research were self efficacy $\left(\mathrm{X}_{1}\right)$ and prior knowledge $\left(\mathrm{X}_{2}\right)$. While the dependent variable in this research is the students' skills (Y). The sample in this research were 108 students of Information and computer technology education IKIP PGRI Pontianak. The analysis technique used is simple regression analysis, and multiple regression analysis. Results of the research: (1) The level of prior knowledge of students of 79146 at intervals of $50.70-99.99$, the level of self-efficacy of students at 56.45 with intervals of 48-65, and the skill level of students at 72.38 with intervals of 51.50 - 81.50. (2) there are significant positive and significant correlation between self efficacy against students' skills by $9.2 \%$. (3) there is a positive and significant influence between the prior knowledge the students' skills of $10.7 \%$. (4) there are significant positive and significant correlation between selfefficacy and prior knowledge the students' skills of $17.4 \%$.
\end{abstract}

Keyword: Self Efficacy, Prior Knowledge, Students’ Skills.

\section{INTRODUCTION}

Education was a natural process that takes place naturally in the human life in the learning environment. In the process, human life increasingly complex and advanced that family education that promotes the formation of a natural person is no longer adequate to deal with the development and progress of science and technology. Education is an important factor for the survival of the nation in all sectors of life. This can be realized by providing an understanding of the scientific material. The academic materials can be obtained through several educational paths.

Formal channels for higher education in West Kalimantan to experience rapid growth. Institute of Teacher Training and Education Indonesian Teachers Association (PGRI Teachers' Training College) Pontianak is one of the institutions that provide education formal higher education level. Formal channels is closely associated with prior knowledge possessed by every human being.
Prior knowledge is a skill that involves knowledge and the development of intellectual skills of students. Prior knowledge is so that students are able to explore the world around through the five senses so that the acquired knowledge students will be able to continue living and becoming a better human being. Prior knowledge of students into one of the important factors that affect the success of the learning process, it can be concluded that the initial knowledge is very important and crucial for the achievement of learning outcomes. Prior knowledge is a part that must be have by every student in order to obtain maximum learning results in line with expectations. Besides the prior knowledge that must be have, the student must also have a good psychomotor skills in order to have the ability to be ready to compete.

Psychomotor skills, especially in the subject of the Advanced Computer Network is the ability to perform the procedures and practices have a professional attitude. Procedure practice (analyzing goals, equipment and materials, setting the pace of work, carry out the 
practice, test circuits, and test circuits) require hard skills were adequate and carried out through a process that requires thinking carefully, skilled, honest, working together, open minded. The work attitude is soft skills that in its application can be extended not only apply in educaton but could also apply to the more general purposes such as in situations where work and in society.

Self efficacy is a person's judgment against himself or level of confidence regarding its ability in a certain task to achieve specific results. More self efficacy expressed reliably predict the scope of career choice, occupational interests, tenacity in difficult areas and personal effectiveness. students with low self-efficacy may avoid subjects that many duties, especially for challenging tasks, while students with higher self-efficacy that has a great desire to do his duties. Confidence is how much confidence about themselves that a person is able to do something or act successfully.

Based on the explanation of the self-efficacy and assignment of initial knowledge, and its relation with the skills that students will do a study to see the effect of self-efficacy and the assignment of initial knowledge of the students' skills. Research will be carried out on students of Education Studies Program Information and Computer Technology course on Advanced Computer Network.

This study aims to: (1) Information about the information of self efficacy, prior knowledge, and skills of students in the subject of Advanced Computer Network course in Information and computer technology education IKIP PGRI Pontianak, (2) The effect of sel efficacy on the skills of students in the subject of Advanced Computer Network course in Information and computer technology education IKIP PGRI Pontianak, (3) Effect prior knowledge of the skills of students in the subject of Advanced Computer Network course in Information and computer technology education IKIP PGRI Pontianak, and (4) The effect of self efficacy and prior knowledge of the skills of students in the subject of Advanced Computer Network course in Information and computer technology education IKIP PGRI Pontianak.

\section{Self Efficacy}

According to Bandura Schunk, Pintrich, \& Meece [1] explains that, "self efficacy is defined as, people judgments of Reviews their capabilities to organize and execute courses of action required to ATTAIN designates the type of performance". Based on these opinions can be interpreted self efficacy assessment of a person of the ability to organize themselves and do the work reflected in the actions undertaken in order to achieve objectives.

Broadly speaking, self efficacy can be categorized into two forms, namely self efficacy and self efficacy is low. Santrock [2] explains, students with low self efficacy in learning can avoid learning task, particularly challenging while students with higher self efficacy will face a challenging task of learning with a great desire.
Students with high self efficacy will be more diligent in learning task than students with low self efficacy.

Woolfolk [3] cites the opinion of Bandura about the sources of self efficacy, namely: enactive mastery experiences, physiological and emotional arousal, vicarious experiences, and verbal persuasion.

\section{Prior Knowledge}

Hailikari [4] defines prior knowledge as a combination of knowledge and skills. According to Gerlach and Ely (Harjanto [5]) prior knowledge can be determined by performing initial tests. Information on previous knowledge of students will assist faculty in determining the appropriate methods for implementing the learning process.

Prior knowledge is a part that must be mastered by every student in order to obtain maximum learning results in line with expectations. This is in line with the statement Yamin [6] that the knowledge and skills needed in the profession, therefore the theoretical knowledge has been provided since the beginning of professional education and skills training programs to support the applicative knowledge.

Sudarma Statement [7] also supported as suggested that prior knowledge students has become one of the important factors that influence the success of learning. By looking at the researchers found, it can be concluded that the initial knowledge is very important and crucial for the achievement of learning outcomes, including the attainment of expertise. Preliminary knowledge will be a provision for students who will develop their potential. Adequate prior knowledge will give a positive implication on achieving better learning outcomes.

\section{Skills}

Nadler [8] is a skill that requires practice or activity can be interpreted as an implication of skills. Sukardi [9] Psychomotor a more knowledge based on the development of mental processes through aspects of muscle and shaping students' skills.

Psychomotor learning outcomes according to Butler [10] into three, namely specific responding, motors chaining and rule using. In responding specific level, students are able to respond to the things that are physical (which can be seen, heard, or touched), or perform a skill that single character, for example holding a racket, holding bed for table tennis. In the motor chaining, students are able to combine more than two basic skills into one combined skills, such as hitting the ball, sawing with calipers. At the level of the rule using the students were able to use his experience to perform complex skills, for example, how to hit the ball accurately to the same energy better results.

\section{METHODS}

\section{Design}

Research on "Effect of Self Efficacy and Prior Knowledge on Students' Skills" using quantitative 
research, in the form of ex-post facto research. The research design used in the study is correlational research. Correlational study used to determine the correlation and look for the value of the influence of self efficacy and prior knowledge of the students' skills in the subject of Advanced Computer Network course in the second semester of Studies Program Information and computer technology education IKIP PGRI Pontianak.

\section{Location Research}

Research on "Effect of Self Efficacy and Prior Knowledge on Students' Skills" conducted in Studies Program Information and computer technology education IKIP PGRI Pontianak in Ampera street No. 88 .

\section{Research Subject}

Subjects used as a data source. Total sample was determined by using the table Issac. Based on the number 165 students population, the number of samples used in this study as many as 108 samples of students. Samples of students were selected using purposive sampling.

\section{Data Analysis Technique}

The obtained data concerns some matters of self efficacy, prior knowledge, and students skill. To obtain data, this study used questioner for self efficacy, documentation from learning outcomes in Basic Computer Network for prior knowledge, and portofolio assessment for students skill in Advance Computer Network.

The data analysis technique used to test the hypothesis aims to prove the hypothesis that there is in research. Hypothesis testing using linear regression analysis and multiple linear SIMPLE. Simple linear regression analysis is used to determine the effect of one independent variable and one dependent variable without the influence of other variables. The analysis carried out is to look for a regression between the self efficacy of the students' skills, prior knowledge of the students' skills.

Multiple linear regression analysis is a linear relationship between two or more independent variables with the dependent variable. This analysis aims to predict the value of the dependent variable when the independent variable values increase or decrease. The result of data analysis for the requierment test is presented in Table 1, 2, and 3.

Table 1 . Normality Test

\begin{tabular}{lccl}
\hline & Normality & & \\
\hline $\begin{array}{l}\text { Self } \\
\text { Efficacy }\end{array}$ & 0.379 & 0.05 & $\begin{array}{l}\text { Normal } \\
\text { distribution }\end{array}$ \\
$\begin{array}{l}\text { Prior } \\
\text { Knowledge }\end{array}$ & 0.526 & 0.05 & $\begin{array}{l}\text { Normal } \\
\text { distribution }\end{array}$ \\
$\begin{array}{l}\text { Students } \\
\text { skills }\end{array}$ & 0.291 & 0.05 & $\begin{array}{l}\text { Normal } \\
\text { Distribution }\end{array}$ \\
\hline
\end{tabular}

Table 2. Linearity Test

\begin{tabular}{lccl}
\hline Variable & $\begin{array}{c}\text { Deviation } \\
\text { from } \\
\text { Linearity }\end{array}$ & Significance & Conclusion \\
\hline Self & 0.611 & 0.05 & Linear \\
$\begin{array}{l}\text { Efficacy- } \\
\text { Students }\end{array}$ & & & \\
Skills & & & \\
Prior & 0.158 & 0.05 & Linear \\
Knowledge- & & & \\
Students & & & \\
Skills & & & \\
\hline
\end{tabular}

Table 3. Multicollinearity Test

\begin{tabular}{lrl}
\hline \multicolumn{1}{c}{ Variable } & $\begin{array}{c}\text { Collinearity } \\
\text { Statistic }\end{array}$ & Conclusion \\
\hline Self Efficacy & 0.978 & Not correlated \\
Prior & 0.978 & Not correlated \\
Knowledge & & \\
\hline
\end{tabular}

Table 1 reveals that the variables, namely self efficacy, prior knowledge, and students skills, both in normal distribution. Table 2 reveals that the variables self efficacy with students skill and prior knowledge and students skills have linear correlation. Table 3 reveals that the variables self efficacy and prior knowledge not have correlation. Based on thus finding, they are applicable in inferential analysis.

\section{RESULT AND DISCUSSION}

\section{Descriptive Analysis}

The data on prior knowledge taken based learning outcome from the basic computer network course, the data on self efficacy taken based questioner, and the data on students skills taken based protofolio assessment. Based on the data, then performed descriptive analysis which presented in Table 4.

Table 4. Descriptive analysis 


\begin{tabular}{lrrrrrrr}
\hline \multicolumn{1}{c}{ Variable } & \multicolumn{1}{c}{ Mean } & \multicolumn{1}{c}{ Median } & \multicolumn{1}{c}{ Modus } & \multicolumn{1}{c}{ Std. Dev } & \multicolumn{1}{l}{ Min } & \multicolumn{1}{c}{ Max } & \multicolumn{2}{c}{ Range } \\
\hline Self efficacy & 56.45 & 56 & 59 & 3.408 & 48 & 65 & 17 \\
Prior knowledge & 79.146 & 80.20 & 99.99 & 10.626 & 50.70 & 99.99 & 49.29 \\
Students skills & 72.38 & 73.25 & 76 & 5.681 & 51.50 & 81.50 & 30
\end{tabular}

Table 4 reveals the statistical analysis results of self efficacy, prior knowledge, and students skills. Statistical analysis of self efficacy shows the score of mean, median, mode, standard deviation, minimun, maximum, and range were 56.45, 56, 59, 3.408, 48, 65, and 17 respectively. Lowest ideal score for self efficacy was 20 and highest ideal scores was 80 . With an mean of self efficacy was 56.45, the self efficicacy fit in good category. Statistical analysis of prior knowledge shows the score of mean, median, mode, standard deviation, minimum, maximum, and range were 79.146, 80.20, 99.99, 10.626, 50.70, 99,99, and 49.29 respectively. Lowest ideal score for prior knowledge was 0 and highest ideal score was 100. With mean of prior knowledge was 79.146, prior knowldege fit in good category. Statistical analysis of students skills show the score of mean, median, mode, standard deviation, minimun, maximum, and range were $72.38,73.25,76$, $5.681,51.50,81.50$, and 30 respectively. Lowest ideal score for students skills was 0 and highest ideal score was 100. With mean of students skills was 72.38, students skill fit in good cateogry. Based on that, self efficacy, prior knowledge, and students skills in advance computer network courses was in good categories.

\section{Effect Self Efficacy on Students' skills}

Effect self efficacy on students' skills in the subject of Advanced Computer Network course in Information and computer technology education IKIP PGRI Pontianak using simple linear regresion. The result of correlation data of self efficacy and student skills used to see magnitude of self efficacy on student skills is presented in table 5 .

Table 5. Corelation of Self Efficacy for Student Skills.

\begin{tabular}{lrrrr}
\hline Model & $\mathrm{R}$ & $\begin{array}{c}\mathrm{R} \\
\text { Square }\end{array}$ & $\begin{array}{c}\text { Adjusted } \\
\mathrm{R} \text { Square }\end{array}$ & $\begin{array}{c}\text { Std. Error of } \\
\text { The } \\
\text { Estimate }\end{array}$ \\
\hline 1 & 0.304 & 0.092 & 0.84 & 5.438 \\
\hline
\end{tabular}

Based on table 5, the magnitude of the correlation value of self efficacy on student skills is accountable by looking at the value of $\mathrm{R}$ in the table. Furthermore, to determine the magnitude of the coefficient of determination refer to $\mathrm{R}$ Square. The magnitude of the correlation coefficient $(\mathrm{R})$ and determination coefficient ( $\mathrm{R}$ Square) are 0.304 and 0.092 . It means $9.2 \%$ of students skills is determined by self efficacy, while $90.8 \%$ of student skills is determined by other factors. This result can be interpreted that the self efficacy provide a positive and significant to increase students skill in advanced computer network courses although still in the low cateogry. The low category of correlation between self efficacy and students skills showed that the role of self efficacy to gain skill in advance computer network course is not maximized.

Simple linear regresion of self efficacy on students skills is a regression calculation of self efficacy towards students skills. Simple linear regresion model has effect, it can be seen from significance value contained in Anova table. The value of variable sig. $<0.05$, simple regression models can be used to predict the students skill. The following table anova can be seen in table 6 .

Table 6. ANOVA Self Efficacy on Student Skills.

\begin{tabular}{lrrrrr}
\hline \multicolumn{1}{c}{ Model } & \multicolumn{1}{c}{$\begin{array}{l}\text { Sum of } \\
\text { Square }\end{array}$} & df & \multicolumn{1}{c}{ Mean } & F & Square \\
& \multicolumn{1}{c}{318.758} & 1 & 318.758 & 10.78 & 0.001 \\
\hline Regresion & 3134.677 & 106 & 29.572 & & \\
Residual & 3134 & & & \\
Total & 3453.435 & 107 & & & \\
\hline
\end{tabular}

Based on table 6 , it is obtained a significance value for student skills at 0.001 . It means self efficacy can be utilized to predict the students skills. The next step is analyze the regresion equition can be seen in table 7 .

Table 7. Coefficients Self Efficacy on Student Skills.

\begin{tabular}{lrcccc} 
Model & \multicolumn{2}{c}{$\begin{array}{l}\text { Unstandardized } \\
\text { Coefficients } \\
\end{array}$} & $\begin{array}{c}\text { Std. } \\
\text { Coef. }\end{array}$ & t & Sig. \\
& & $\begin{array}{l}\text { Std. } \\
\text { Error }\end{array}$ & Beta & & \\
& & & & \\
\hline Constant & 43.789 & 8.724 & & 5.019 & 0.000 \\
Self & 0.506 & 0.154 & 0.304 & 3.283 & 0.001 \\
Efficacy & & & & & \\
\hline
\end{tabular}

Table 7 reveals the regresion equation, namely the constant value (a) amounted to 43.789 and regresion coefficient self efficacy of 0.506 . Based on coefficient table, the value of statistical significance (Sig.) on constant and self efficacy shows $\leq 0.05$, and the regression model can be used to determine the value of students skills. The regression equation obtained:

$\mathrm{Y}=43.789+0.506 \mathrm{X}_{1}$

The constant value of 43.789 indicates if there is no self efficacy $\left(\mathrm{X}_{1}\right)$ then students skills $(\mathrm{Y})$ score is 43.789 . Regression coefficient of 0.506 indicates each additional self efficacy $\left(\mathrm{X}_{1}\right)$ score will improve students skills (Y) of 0.506 .

\section{Effect Prior Knowledge on Students' skills}

Effect prior knowledge on students' skills in the subject of Advanced Computer Network course in Information and computer technology education 
program, IKIP PGRI Pontianak using simple linear regresion. The result of correlation data of prior knowledge and student skills used to see magnitude of prior knowledge on student skills is presented in table 8 .

Table 8. Corelation of Prior Knowledge for Student Skills.

\begin{tabular}{ccccc}
\hline Model & $\mathrm{R}$ & $\begin{array}{c}\mathrm{R} \\
\text { Square }\end{array}$ & $\begin{array}{c}\text { Adjusted } \\
\text { R Square }\end{array}$ & $\begin{array}{c}\text { Std. Error of } \\
\text { The } \\
\text { Estimate }\end{array}$ \\
\hline 1 & 0.328 & 0.107 & 0.99 & 5.392
\end{tabular}

Based on table 8 , the magnitude of the correlation value of prior knowledge on student skills is accountable by looking at the value of $\mathrm{R}$ in the table. Furthermore, to determine the magnitude of the coefficient of determination refer to $\mathrm{R}$ Square. The magnitude of the correlation coefficient $(\mathrm{R})$ and determination coefficient ( $\mathrm{R}$ Square) are 0.328 and 0.107 . It means $10.7 \%$ of students skills is determined by prior knowledge, while $89.3 \%$ of student skills is determined by other factors. This result can be interpreted that the prior knowledge provide a positive and significant to increase students skill in advanced computer network courses although still in the low cateogry. The low category of correlation between prior knowledge and students skills showed that the role of self efficacy to gain skill in advance computer network course is not maximized.

Simple linear regresion of prior knowledge on students skills is a regression calculation of prior knowledge towards students skills. Simple linear regresion model has effect, it can be seen from significance value contained in Anova table. The value of variable sig. $<0.05$, simple regression models can be used to predict the students skill. The following table anova can be seen in table 9 .

Table 9. ANOVA Prior Knowledge on Student Skills.

\begin{tabular}{lrrrrr}
\hline Model & \multicolumn{1}{c}{$\begin{array}{c}\text { Sum of } \\
\text { Square }\end{array}$} & df & $\begin{array}{r}\text { Mean } \\
\text { Square }\end{array}$ & F & Sig. \\
\hline Regresion & 371.121 & 1 & 371.121 & 12.76 & 0.001 \\
Residual & 3082.314 & 106 & 29.078 & & \\
Total & 3453.435 & 107 & & & \\
\hline
\end{tabular}

Based on table 9 , it is obtained a significance value for student skills at 0.001 . It means prior knowledge can be utilized to predict the students skills. The next step is analyze the regresion equition can be seen in table 10 .

Table 10. Coefficients Prior Knowledge on Student Skills.

\begin{tabular}{lrllrr}
\hline \multicolumn{1}{c}{ Model } & \multicolumn{2}{c}{ Unstandardized } & Std. & t & Sig. \\
& \multicolumn{2}{c}{ Coefficients } & Coef. & & \\
& B & Std. & Beta & & \\
& & Error & & & \\
\hline Constant & 58.508 & 3.917 & & 14.49 & 0.000 \\
Prior & 0.175 & 0.049 & 0.328 & 3.57 & 0.001 \\
Knowledg & & & & & \\
\hline
\end{tabular}

Table 10 reveals the regresion equation, namely the constant value (a) amounted to 58.508 and regresion coefficient self efficacy of 0.175 . Based on coefficient table, the value of statistical significance (Sig.) on constant and prior knowledge shows $\leq 0.05$, and the regression model can be used to determine the value of students skills. The regression equation obtained:

$\mathrm{Y}=58.508+0.175 \mathrm{X}_{2}$

The constant value of 58.508 indicates if there is no prior knowledge $\left(\mathrm{X}_{2}\right)$ then students skills $(\mathrm{Y})$ score is 58.508. Regression coefficient of 0.175 indicates each additional prior knowledge $\left(\mathrm{X}_{2}\right)$ score will improve students skills (Y) of 0.175 .

\section{Effect Self Efficacy and Prior Knowledge on Students'} skills

Effect self efficacy $\left(\mathrm{X}_{1}\right)$ and prior knowledge $\left(\mathrm{X}_{2}\right)$ on students' skills (Y) in the subject of Advanced Computer Network course in Information and computer technology education program, IKIP PGRI Pontianak using multiple linear regresion. The result of correlation data of self efficacy, prior knowledge and student skills used to see magnitude of self efficacy and prior knowledge on student skills is presented in table 11.

Table 11. Corelation of Self Efficacy and Prior Knowledge for Student Skills.

\begin{tabular}{ccccc}
\hline Model & $\mathrm{R}$ & $\begin{array}{c}\mathrm{R} \\
\text { Square }\end{array}$ & $\begin{array}{c}\text { Adjusted } \\
\mathrm{R} \text { Square }\end{array}$ & $\begin{array}{c}\text { Std. Error of } \\
\text { The } \\
\text { Estimate }\end{array}$ \\
\hline 1 & 0.417 & 0.174 & 0.158 & 5.212 \\
\hline
\end{tabular}

Based on table 11, the magnitude of the correlation value of sefl efficacy and prior knowledge on student skills is accountable by looking at the value of $\mathrm{R}$ in the table. Furthermore, to determine the magnitude of the coefficient of determination refer to $\mathrm{R}$ Square. The magnitude of the correlation coefficient (R) and determination coefficient ( $\mathrm{R}$ Square) are 0.417 and 0.174 . It means $17.4 \%$ of students skills is determined by self efficacy and prior knowldge, while $82.6 \%$ of student skills is determined by other factors.

Multiple linear regresion of self efficacy and prior knowledge on students skills is a regression calculation of self efficacy and prior knowledge towards students skills. Multiple linear regresion model has effect, it can be seen from significance value contained in Anova table. The value of variable sig. $<0.05$, multiple regression models can be used to predict the students skill. The following table anova can be seen in table 12 .

Table 12. ANOVA Self Efficacy and Prior Knowledge on Student Skills.

\begin{tabular}{lrrrrr}
\hline \multicolumn{1}{c}{ Model } & \multicolumn{1}{c}{$\begin{array}{c}\text { Sum of } \\
\text { Square }\end{array}$} & df & $\begin{array}{c}\text { Mean } \\
\text { Square }\end{array}$ & F & Sig. \\
\hline Regresion & 601.49 & 2 & 300.747 & 11.07 & 0.000 \\
Residual & 2851.941 & 105 & 27.161 & & \\
Total & 3453.435 & 107 & & & \\
\hline
\end{tabular}


Based on table 12, it is obtained a significance value for student skills at 0.000 . It means self efficacy and prior knowledge can be utilized to predict the students skills. The next step is analyze the regresion equition can be seen in table 13 .

Table 13. Coefficients Self Efficacy and Prior Knowledge on Student Skills.

\begin{tabular}{|c|c|c|c|c|c|}
\hline \multirow[t]{2}{*}{ Model } & \multicolumn{2}{|c|}{$\begin{array}{l}\text { Unstandardized } \\
\text { Coefficients }\end{array}$} & \multirow{2}{*}{$\begin{array}{c}\text { Std. } \\
\text { Coef. } \\
\text { Beta }\end{array}$} & \multirow[t]{2}{*}{$\mathrm{t}$} & \multirow[t]{2}{*}{ Sig. } \\
\hline & B & $\begin{array}{l}\text { Std. } \\
\text { Error }\end{array}$ & & & \\
\hline Constant & 35.564 & 8.74 & & 4.07 & 0.000 \\
\hline $\begin{array}{l}\text { Self } \\
\text { Efficacy }\end{array}$ & 0.435 & 0.15 & 0.26 & 2.91 & 0.004 \\
\hline $\begin{array}{l}\text { Prior } \\
\text { Knowledge }\end{array}$ & 0.155 & 0.05 & 0.29 & 3.23 & 0.002 \\
\hline
\end{tabular}

Table 13 reveals the regresion equation, namely the constant value (a) amounted to 35.564, regresion coefficient self efficacy of 0.435 , and regresion coefficient prior knowledge of 0.155. Based on coefficient table, the value of statistical significance (Sig.) on constant and independent vairable shows $\leq$ 0.05 , and the regression model can be used to determine the value of students skills. The regression equation obtained:

$\mathrm{Y}=35.564+0.435 \mathrm{X}_{2}+0.155 \mathrm{X}_{1}$

The constant value of 35.564 indicates if there is no self efficacy $\left(\mathrm{X}_{1}\right)$ and prior knowledge $\left(\mathrm{X}_{2}\right)$ then students skills (Y) score is 35.564. Regression coefficient of model indicates each additional self efficacy $\left(\mathrm{X}_{1}\right)$ and prior knowledge $\left(\mathrm{X}_{2}\right)$ score will improve students skills (Y) of $0.435+0.155=0.590$. Based on regresion equation can be concluded that the more dominant variable in influencing students' skills is self efficacy.

\section{CONCLUSION}

Based on the research and the data analysis of this research on the Effect of Self Efficacy and Prior Knowledge againts Students Skills in Advanced Computer Networking, can be conclusion level of prior knowledge, self-efficacy, and skills of students in the Advance Computer Networks fit in good category from their mean value. The level of self-efficacy of students at 56.45 with intervals of $48-65$, the level of prior knowledge of students of 79146 at intervals of 50.70 99.99, and the students skill level at 72.38 with intervals of $51.50-81.50$.

There is a positive and significant effect between self efficacy against students 'skills in the Advance Computer Network Course. The magnitude of the effect of selfefficacy on the skills of students in the Advance Computer Network Course at 9.2\%. This magnitude indicates that there is a relationship, but in low category. Therefore, student self efficacy need to be impoved in advanced computer network course.
There is a positive and significant effect between prior knowledge againts students skills in the Advanced Computer Network Course. The magnitude of the effect of prior knowledge on the students skills in the Advanced Computer Network at $10.7 \%$. This magnitude indicates that there is a relationship, but in low category. Therefore, student prior knowledge need to be impoved in advanced computer network course.

There is a positive and significant influence between prior knowledge and self efficacy againts students 'skills in the Advanced Computer Network. The magnitude of the effect of variable self efficacy and prior knowledge againts students skills in the Advanced Computer Network at $17.4 \%$.

\section{REFERENCES}

[1] Schunk, D.H., Pintrich, P.R., and Meece, J.R. Motivation in Education: Theory, Research, and Applications 4th Edition. New York: Pearson, 2013.

[2] Santrock, J.W. Educational Psychology, $4^{\text {th }}$ Edition. Pennsylvania: McGraw-Hill Education, 2009.

[3] Woolfolk, A. Educational Psychology, Boston: Pearson Education, Inc. 2007.

[4] Hailikari, T. Assessing university students' prior knowledge: Implications for theory and practice. Helsinki: University of Helsinki Press, 2009.

[5] Harjanto. Perencanaan Pengajaran. Jakarata: Rineka Cipta, 2006.

[6] Yamin, M. Sertifikasi Profesi Keguruan di Indonesia. Jakarta:Gaung Persada Press, 2006.

[7] Sudarma, I. K. "Pengaruh PenerapanStrategi Pembelajaran dan Pengetahuan Awal terhadap Pemahaman KonsepSains dan Sikap Ilmiah Siswa Kelas V di Sekolah Dasar". Desertation. Post Graduate Program, Univerity of Malang.

[8] Nadler, D.A. (1997). Managing Organitational Behaviour. Boston : Toronto, Little Brown and Company, 2013.

[9] Sukardi.. Evaluasi Pendidikan. Jakarta:Bumi Aksara, 2011.

[10] Butler, R.C. Instructional System Development for Vocational and Technical Training. Englewood. Cliffs, NJ: Educational Technology Publication, 1972. 